\title{
ANALYSIS OF ABO GROUP DISCREPANCIES IN A TERTIARY CARE CENTRE SOUTH INDIA
}

\author{
Bonagiri Shanthi' ${ }^{1}$ K. Ravi Babu²
}

${ }^{1}$ Associate Professor, Department of IHBT, Nizam's Institute of Medical Sciences.

${ }^{2}$ Senior Resident, Department of Bio-Chemistry, Nizam's Institute of Medical Sciences.

\section{ABSTRACT}

\section{BACKGROUND}

ABO system remains the most important blood group system in transfusion and organ transplantation medicine. ABO typing and $\mathrm{ABO}$ incompatibility testing remain the foundation of all pretransfusion testing. An inverse reciprocal relationship exists between the presence of A and B antigens on red cells and the presence of Anti-A and Anti-B or both in sera. Discrepancies in ABO grouping can be characterised by inappropriate results in either cell or serum grouping.

The aim of this study is to analyse commonly occurring ABO group discrepancies in order to standardise resolving procedure and avoid delay in pretransfusion testing.

\section{MATERIALS AND METHODS}

Descriptive study period included from 2012 to 2016, the pretransfusion tests done by tube and gel column agglutination method. Total 28,024 blood grouping and typing tests were retrospectively evaluated in the study.

\section{RESULTS}

ABO blood group discrepancies were identified in 1331 cases, which is equal to $4.75 \%$ of total tests. Subgroups of A in 1089 cases (81\%), Autoantibodies in 187 cases (14.5\%), Alloantibodies in 33 cases (2.56\%), 16 cases were typed as Bombay phenotype and 8 as $\mathrm{H}$ deficient probably, Para-Bombay phenotype and two cases of multiple myeloma and heparin contaminated sample causing discrepancy in cell grouping. These cases were identified during pretransfusion workup.

\section{CONCLUSION}

Resolving $\mathrm{ABO}$ and $\mathrm{Rh}$ grouping and typing discrepancy is crucial in pretransfusion testing and selecting proper blood and blood products in transfusion services. Most of the problems can be resolved by basic immunohaematological techniques.

\section{KEYWORDS}

ABO Blood Group System, Discrepancies, Red Cell Serology.

HOW TO CITE THIS ARTICLE: Shanthi B, Babu KR. Analysis of ABO group discrepancies in a tertiary care centre South India. J. Evolution Med. Dent. Sci. 2017;6(79):5615-5618, DOI: 10.14260/jemds/2017/1218

\begin{abstract}
BACKGROUND
The ABO group system was the first of the 33 current blood group systems ${ }^{[1,2]}$ to be identified and is the most significant for transfusion medicine practice. Accurate pretransfusion testing is fundamental for the prevention of haemolytic transfusion reactions (HTRs), which starts with the ABO blood group test performed in two steps. ${ }^{[3]}$ The forward type is commonly carried out through monoclonal antisera to establish whether A or B antigens are present on the RBCs. The reverse type is a complementary test based on the inverse reciprocal relationship between the presence of $A$ and $B$ antigens on erythrocytes and the presence of naturally occurring antibodies in their sera. Both tests can be carried out through slide, tube, microplate or column agglutination techniques. Use of lectins Anti-A1, Anti-H, Anti-AB in cell grouping and $\mathrm{A} 1$ cells, $\mathrm{B}$ cells and $\mathrm{O}$ cells serum grouping will detect any type of $\mathrm{ABO}$ group discrepancies including sub-
\end{abstract}

'Financial or Other Competing Interest': None.

Submission 28-08-2017, Peer Review 22-09-2017,

Acceptance 27-09-2017, Published 30-09-2017.

Corresponding Author:

Dr. Bonagiri Shanthi,

Associate Professor,

Department of Immuno-haematology and Blood Transfusion,

Nizam's Institute of Medical Sciences,

Hyderabad-500034, Telangana, India.

E-mail: shanthikoppukonda@yahoo.com

DOI: $10.14260 /$ jemds $/ 2017 / 1218$ groups, $\mathrm{H}$ deficient/ absent groups, unexpected alloantibodies, autoantibodies, etc.

ABO discrepancies can be defined as difference between cell and serum grouping. The discrepancy may arise because of technical errors, underlying clinical background and treatment the patient is receiving, age and genetic inheritance of blood group antigens.[4] All technical errors include specimen mix-up, too heavy or too light RBC suspension, failure to add reagents, missed observation of haemolysis, failure to comply with the manufacturer's instructions, under- or over-centrifugation of test samples, incorrect interpretation or recording of the test results, contaminated reagents or dirty glassware and expired or otherwise inactive reagents. Technical factors suspected to cause the ABO discrepancy should be reviewed and corrected. If the discrepancy appears to be due to an error in specimen collection or identification, a new sample should be drawn from the patient and the forward and reverse grouping repeated.

ABO typing discrepancies may be caused by intrinsic problems with either RBCs or serum and can be classified in five categories: i) Weak/missing $\mathrm{RBC}$ reactivity, resulting from weak ABO subgroup inheritance, leukaemia/malignancy, transfusion, transplantation and excessive soluble blood group substance; ii) Extra RBC reactivity caused by autoagglutinins/excess proteins coating RBCs, nonspecific RBC aggregation due to abnormal concentrations of serum proteins or infused macromolecular solutions, $\mathrm{pH}$ - or 
reagent-dependent antibody or rouleaux, transplantation, acquired A antigen, acquired B-like antigen and out-of-group transfusion; iii) Mixed-field RBC reactivity for recent transfusion, transplantation, foeto-maternal haemorrhage and chimerism; iv) Weak/missing serum reactivity due to age ( $<4-6$ months old or elderly persons), ABO subgroups, hypogammaglobulinaemia and transplantation; v) Extra serum reactivity caused by cold auto- or allo-antibodies, antibodies to reagent constituent, excess serum protein, transfusion of plasma, transplantation or infusion of intravenous immunoglobulin.[5]

\section{Aim of the Study}

To analyse commonly occurring $\mathrm{ABO}$ group discrepancies in order to standardise resolving procedure and avoid delay in pretransfusion testing.

\section{MATERIALS AND METHODS}

This is a descriptive study over a period of 4 years (2012 2016). Total of 28,024 ABO blood grouping tests were analysed retrospectively for discrepancies at the Department of Transfusion Medicine, referral centre. ABO typing was done using gel column agglutination method. The ABO-Rh D/Reverse Typing Cassette consists of six columns, five of which contain gel, buffers and reagents including anti-A, anti$B$, anti-D, A1 cells and B cells. The sixth column serves as a negative control well; it only contains the red cell suspension of the sample. During the centrifugation of the cassettes, nonagglutinated red cells sink to the bottom of the column, while agglutinated red cells remain at different levels of the column according to the amount of agglutination. The reactions are graded as Traces $1+, 2+, 3+$ or $4+$ to represent the strength of the reaction.

Antibodies were screened by column agglutination technology (CAT) using commercially available three cell antigen panel by Coombs gel card. Whenever antibody screening was positive, extended eleven cell panel was used for antibody identification using low ionic strength saline (LISS).

In $\mathrm{ABO}$ typing by the reference manual method for forward typing, one drop each of anti-A and anti-B reagent was added to each test tube containing one drop of $2 \%-5 \%$ red cell suspension. For reverse typing, one drop of each of A and $B$ cell reagents was added to each test tube containing two drops of the plasma sample. As an auto control, the red cells and serum of the sample were reacted together in another test tube. Samples that showed discrepant results after retesting were tested by additional manual methods were re-evaluated by using anti-AB, anti- $\mathrm{H}$ and anti-A1 (Dolichos biflorus and Ulex europaeus lectin) reagents.[6] If cold agglutinins were suspected, the sample was collected and immediately incubated at $37^{\circ} \mathrm{C}$ and at room temperature for 30 mins. after saline washing and then retested. Interpretation of test results were described as the reaction grades obtained with each method. Finally, results showing extra cell or serum reactions (including any reaction grade) were regarded as discrepant results.

\section{Statistical Analysis}

The percentage of discrepant results was calculated.

\section{RESULTS}

Discrepancy was found in 1331 (4.75\%) of 28,024 ABO grouping tests. Total sub-groups of $A$ and $B$ detected with Anti-A1, AB and $\mathrm{H}$ lectin were 1089 out of 28,024 blood grouping and typing tests accounting for $81 \%$ (Fig. 1) of blood group discrepancies in our lab, labelled as $\mathrm{A} 2$ or $\mathrm{A} 2 \mathrm{~B}$, $\mathrm{A} 3$ and Bx. Discrepancy caused by red cell autoantibodies was observed in 187 cases (14.5\%), in that causing panagglutination was observed in $69 / 187$ cases by cold autoantibodies (37\%), rest of discrepancies were because of mixed and warm autoantibodies. Rare blood group phenotypes, which caused unexpected antibody considered as Bombay in 16 patients (1.2\% of discrepancies) and ParaBombay in 6 patients. Red cell alloantibodies accounted for $2.5 \%$ of total $\mathrm{ABO}$ discrepancies. Three and 11 cell panel antibody identification revealed red cell antibodies like AntiD, Anti-E, Kell, Lewis and MNS. Forward group discrepancy was observed in multiple myeloma[7] and patient on heparin therapy. Mixed field reaction was observed in one case of allogenic bone marrow stem cell transplantation and group 0 red cell transfusions to $\mathrm{A} / \mathrm{B} / \mathrm{AB}$ patients. The discrepant results were grouped into IV types (Table 2 ).

\begin{tabular}{|c|c|c|c|c|c|c|c|c|c|c|c|}
\hline \multirow{5}{*}{ Discrepancy } & Diagnosis & $\begin{array}{c}\text { Bombay } \\
\text { H-Absent }\end{array}$ & A2B & $\begin{array}{c}\text { Bone } \\
\text { Marrow } \\
\text { Tx }\end{array}$ & old Age & $\begin{array}{l}\text { Cold Auto- } \\
\text { antibody }\end{array}$ & $\begin{array}{c}\text { Alloanti } \\
\text { body }\end{array}$ & H-Deficient & Bx & $\begin{array}{c}\text { H- } \\
\text { Deficient }\end{array}$ & $\begin{array}{c}\text { Warm } \\
\text { Auto- } \\
\text { Antibody }\end{array}$ \\
\hline & \begin{tabular}{|c|} 
Group of \\
Discrepancy
\end{tabular} & IV & II & I & I & IV & IV & II & II & II \& IV & IV \\
\hline & \begin{tabular}{|c|} 
Type of \\
Discrepancy
\end{tabular} & $\begin{array}{c}\text { Extra } \\
\text { antibody }\end{array}$ & $\begin{array}{l}\text { Weak Anti A } \\
\text { expression }\end{array}$ & $\begin{array}{c}\text { Mixed field } \\
\text { reaction }\end{array}$ & $\begin{array}{c}\text { Missing } \\
\text { antibody }\end{array}$ & $\begin{array}{c}\text { Extra } \\
\text { antibody }\end{array}$ & $\begin{array}{c}\text { Extra } \\
\text { antibody }\end{array}$ & $\begin{array}{l}\text { No antigen } \\
\text { expression }\end{array}$ & $\begin{array}{l}\text { Weak Anti B } \\
\text { expression }\end{array}$ & $\begin{array}{c}\text { Extra } \\
\text { antibody }\end{array}$ & $\begin{array}{c}\text { Extra } \\
\text { antibody }\end{array}$ \\
\hline & Serum & Unknown & B & B & $\mathrm{AB}$ & 0 & 0 & B & B & Unknown & 0 \\
\hline & Cell & 0 & $\mathrm{Ab}$ & Unknown & $\mathrm{B}$ & $\mathrm{AB}$ & $\mathrm{B}$ & 0 & 0 & 0 & $\mathrm{~B}$ \\
\hline \multirow{3}{*}{$\begin{array}{l}\text { Serum } \\
\text { Grouping }\end{array}$} & 0 cells & $4+$ & 0 & & 0 & $2+$ & $3+$ & 0 & 0 & $4+$ & $2+$ \\
\hline & B cells & $4+$ & 0 & 0 & 0 & $3+$ & $3+$ & $2+$ & 0 & $4+$ & $4+$ \\
\hline & A1 cells & $4+$ & $1+$ & $4+$ & 0 & $4+$ & $4+$ & 0 & $4+$ & $4+$ & $4+$ \\
\hline \multirow{7}{*}{$\begin{array}{c}\text { Cell } \\
\text { Grouping }\end{array}$} & Anti-H & 0 & $3+$ & $3+$ & $2+$ & $2+$ & $2+$ & 0 & $4+$ & \begin{tabular}{|c|} 
Weak and \\
delayed \\
expression
\end{tabular} & $2+$ \\
\hline & Anti-B & & $1+$ & $2+$ & 0 & $2+$ & $2+$ & 0 & $4+$ & $4+$ & $2+$ \\
\hline & Anti-A1 & 0 & 0 & 0 & 0 & $2+$ & 0 & 0 & 0 & $4+$ & $4+$ \\
\hline & Anti-D & 0 & $4+$ & $4+$ & $4+$ & $4+$ & 0 & 0 & $4+$ & $4+$ & $4+$ \\
\hline & Anti-B & 0 & $3+$ & MF & $3+$ & $4+$ & $4+$ & 0 & 0 & 0 & $2+$ \\
\hline & Anti-A & 0 & $2+$ & 0 & 0 & $3+$ & 0 & 0 & 0 & 0 & 0 \\
\hline & Sl. No. & 1 & 2 & 3 & 4 & 5 & 6 & 7 & 8 & 9 & 10 \\
\hline
\end{tabular}




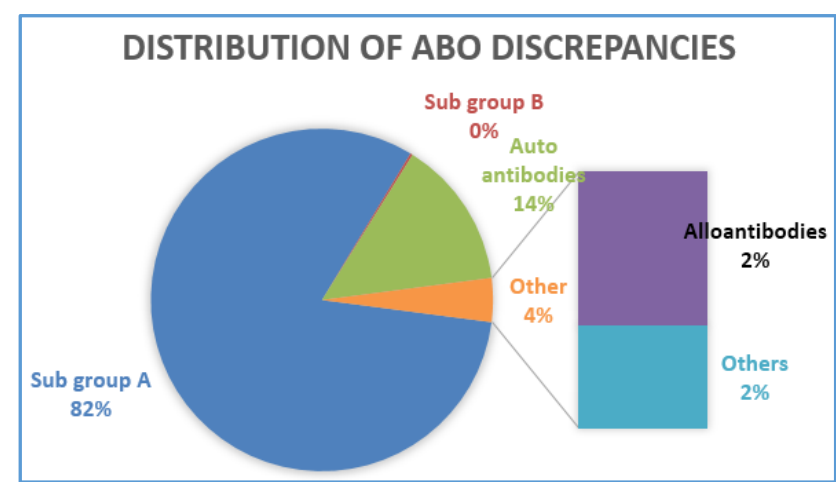

Figure 1. Distribution of ABO Discrepancies in our Centre

\section{DISCUSSION}

ABO blood group testing is the basis for pretransfusion testing to select accurate blood unit for transfusion. In addition, $\mathrm{ABO}$ blood group is very important in identification, blood donor group, bone marrow and solid organ transplantation. An ABO incompatible red blood cells transfusion is a leading cause of death from transfusion.[3] Subgroups, alloantibodies and autoantibodies are the common reasons for $\mathrm{ABO}$ discrepancies in routine immunohaematology practice. ${ }^{[4,5]}$

In our descriptive study, after sub-groups autoantibodies are the main reason for $\mathrm{ABO}$ group discrepancies. And it is essential to decide $\mathrm{ABO}$ group in such cases to select the least incompatible blood unit with limited inventory of $0, \mathrm{RH}$ negative red cells. For that we can use auto-adsorption of antibodies at cold/warm temperature and elution technique to resolve the discrepancy. Cold agglutinins usually cause panagglutination and cell group shows $A B$ group and serum 0 group. In such cases, instructions were given to collect blood sample in warm condition $\left(3^{\circ} \mathrm{C}\right) .{ }^{[8]}$ Auto control test is useful in differentiating warm autoagglutinins and clinically significant alloantibodies if there is unexpected antibody in serum grouping.

In this study $\mathrm{ABO}$ discrepancies occurred because of alloantibodies at all phases of reactions by different types of antibodies, mainly IgM at $4^{\circ} \mathrm{C}$ and room temperature (Anti-M and Anti-E) at $37^{\circ} \mathrm{C}$ and $\mathrm{AHG}$ phase Anti-D, Anti-C, Kidd etc. Antibody identification with 3 cell and 11 cell panel was done at 3 phases to detect antibody, resolve serum discrepancy and selection of suitable blood unit.[9]

Identification of sub-groups is possible with lectins Anti$\mathrm{A} 1$, Anti-H and Anti-AB reagents. In our study, these reagents in routine red cell serology and saliva testing detected subgroups, Bombay phenotype and Para-Bombay phenotypes. Family ABO group testing helps in confirming $\mathrm{H}$ deficient/Bombay phenotype and other rare blood groups.[10] Blood group genotyping confirms the diagnosis for such discrepant results.

Thirty nine year old female diagnosed case of Acute Myeloid Leukaemia, O RH positive group received allogenic peripheral blood stem cell transplantation from stem cell donor of B RH positive group, after three months ABO grouping and typing showed mixed field reaction with Anti-B in cell group. Blood group chimerism is an intrinsic characteristic of ABO non-identical HPC transplantation. The erythrocyte chimerism[11] helps in using the blood products with donor $\mathrm{ABO}$ typing or not. In our case, patient showed full-donor chimera indicating successful engraftment.

\section{CONCLUSION}

ABO blood grouping is the first and foremost investigation in blood transfusion services. If $\mathrm{ABO}$ discrepancies are found, they have to be resolved by starting with the basic direct Coomb's test, Indirect Coomb's test and auto control. Most of them can be resolved serologically even before resorting for high end investigations. However, it is essential to strictly adhere to the standard operating procedures, from sample collection to laboratory practices, to avoid delayed turnaround time for issuing blood components. In case of delay in resolving the discrepancy coordination between the clinician, laboratory values, ongoing treatment and transfusion medicine specialist are mandatory to decide the blood product to be selected for transfusion.

Molecular ABO genotyping[12] in confirming rare subgroups, Bombay/Para-Bombay phenotypes is very useful to reaffirm our basic red cell serology methods to resolve these unusual $\mathrm{ABO}$ discrepancies.

\section{REFERENCES}

[1] Landsteiner K. Zur Kenntnis der antifermentativen, lytischen und agglutinierenden Wirkungen des Blutserums und der Lymphe. Zentralblatt Bakteriologie 1900;27:357-62.

[2] Mitra R, Mishra N, Rath GP. Blood groups systems. Indian J Anaesth 2014;58(5):524-8.

[3] Khan MN, Khan TA, Ahmed Z. Discrepancy in ABO blood grouping. J Coll Physicians Surg Pak 2013;23(8):590-2.

[4] Arumugam P, Hamsavardhini S, Ravishankar J, et al. Resolving ABO discrepancies by serological workupan analysis of few cases. International Journal of Research in Medical Sciences 2017;5(3):893-900.

[5] Franchini M, Liumbruno GM. ABO blood group: old dogma, new perspectives. Clin Chem Lab Med 2013;51(8):1545-53.

[6] Shastry S, Bhat S. Imbalance in A2 and A2B phenotype frequency of $\mathrm{ABO}$ group in South India. Blood Transfus 2010;8(4):267-70.

[7] Park J, Jekarl DW, Park SY, et al. Combined group I and III ABO discrepancies in multiple myeloma with IgGlambda type: a case report. Med Princ Pract 2017;26(1):90-2.

[8] Ness PM. How do I encourage clinicians to transfuse mismatched blood to patients with autoimmune hemolytic anemia in urgent situations? Transfusion 2006;46(11):1859-62.

[9] Wennersten P, Sutor LJ. A case of masquerading alloantibodies: the value of a multitechnique approach. Immunohematology 2014;30(3):117-20.

[10] Jonnavithula N, Bonagiri S, Ramachandran G, et al. Peri-operative red cell transfusion management in a rare H-deficient (Para-Bombay) blood group variant. Indian J Anaesth 2013;57(1):78-9. 


\section{Jemds.com}

[11] Gajewski JL, Johnson VV, Sandler SG, et al. A review of transfusion practice before, during, and after hematopoietic progenitor cell transplantation. Blood 2008;112(8):3036-47.
Original Research Article

[12] Altayar MA. Next generation sequencing-based genotyping of human blood groups: FY, JK and ABO genes (Doctoral dissertation, University of Plymouth). 2017. 